\title{
Wacana Pro Kontra Pilkada Serentak di Masa Pandemi Covid-19 pada Pemberitaan Online
}

\author{
Diah Arum Hapsari ${ }^{1 *}$ \\ ${ }^{* 1}$ Tadris Bahasa Indonesia, Fakultas \\ Adab dan Bahasa, IAIN Surakarta, \\ Sukoharjo, Jawa Tengah, Indonesia \\ *email: diaharumhapsari@gmail.com
}

Received: 14 Desember 2020

Accepted: 27 Maret 2021

Published: 27 Maret 2021

doi: $10.22236 /$ imajeri.v3i2.6066

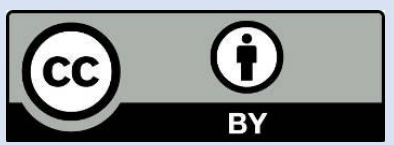

(C) 2021 Oleh authors. Lisensi Imajeri: Jurnal Pendidikan Bahasa dan Sastra Indonesia, Uhamka, Jakarta. Artikel ini bersifat open access yang didistribusikan di bawah syarat dan ketentuan Creative Commons Attribution (CC-BY) license.

(http://creativecommons.org/licenses/by/4.0/).

\begin{abstract}
Abstrak
Pilkada pada masa pandemi dilakukan dengan serentak. Hal ini membuat banyak opini yang berkembang di pemberitaan online. Penelitian ini bermasksud untuk mendeskripsikan struktur makro, superstruktur dan mikro dalam wacana pro kontra pilkada serentak di masa pandemi covid-19 pada pemberitan online kompas.com edisi 24 September 2020. Metode yang digunakan dalam penelitian ini berupa linguistik deskriptif dengan data berupa kata, kalimat, dan ungkapan pada wacana pro dan kontra pilkada serentak di masa pandemi covid-19 pada pemberitan online kompas.com edisi 24 September 2020. Teknik analisis data dalam penelitian ini menggunakan teori milik Teun Van Dijk (guna menganalisis wacana) dan juga menggunakan model analisis interaktif. Hasil menunjukkan bahwasanya semua struktur dalam teori Teun Van Dijk ditemukan dalam wacana ini.
\end{abstract}

Kata kunci: Wacana; Pemberitaan Online; Teun Van Dijk;

\section{Abstract}

Pilkada during the pandemic was carried out simultaneously. This makes a lot of opinions that develop in online news. This study aims to describe the amcro, superstructure, and micro structures in the concurrent regional election pros and cons discourse during the Cocid-19 pandemic in the online publication of Kompas.com 24 September 2020 edition. The method used in this research is descriptive linguistics with data in the form of words, sentences, and expressions in the discourse of the pros and cons discourse during the Cocid-19 pandemic in the online publication of Kompas.com 24 September 2020 edition. The data analysis technique in this study uses Teun Van Dijk's theory (to analyze discourse) and also uses an analytical model interactive. Result shows that all the structures in Teun Van Dijk's theory are found in this discourse.

Keywords: Online News; Discourse: Teun Van Dijk;

\section{PENDAHULUAN}

Media massa online di era serba canggih ini dianggap lebih efektif dibandingkan dengan media massa cetak. Dianggap demikian karena media massa online lebih memudahkan masyarakat dalam pencarian sebuah informasi dan waktu yang digunakan dalam penyebaran informasi baru sangatlah cepat, selain itu media massa online juga tidak menghasilkan timbunan kertas setelah selesai membacanya. Hal tersebut sesuai dengan Nurkinan (2017), yang menuliskan bahwa melalui media online/internet mampu memberikan informasi sesuai 
dengan kebutuhan secara cepat/instan, dan kecepatan tersebut tidak dibatasi oleh adanya ruang dan waktu sehingga memungkinkan dan memudahkan siapapun untuk dapat mengakses informasi di mana pun dan kapan pun itu. Fitriana (2019) mengungkapkan bahwa massa online digunakan sebagai penyampai informasi daring yang dikemas dengan bentuk wacana ke hadapan publik, baik itu berasal dari individu, kelompok, maupun instansi pemerintahan. Namun demikian, karena kecepatan informasi yang disajikan, maka tidak jarang teks yang disajikan memunculkan pro dan kontra (Boer, Pratiwi, and Muna 2020; Suprapto 2020)

Berbicara terkait wacana, lekat hubungannya dengan studi linguistik. hal ini diperkuat oleh Baryadi (2002) yang mengungkapkan bahwa istilah wacana dan discourse banyak ditemukan dan digunakan dalam linguistik. Dalam studi linguistik biasanya wacana akan dianalisis penggunaan bahasa baik lisan maupun tulisannya dengan dasar berbagai teori yang telah ada. Analisis wacana sendiri merupakan ilmu yang mengkaji terkait fungsi bahasa atau penerapan pemakaian bahasa dalam hal komunikasi (Darma 2009; Suwandi 2008). Selain itu, dalam studi linguistik juga dikenal dengan analisis wacana kritis (AWK), di antara analisis wacana dan analisis wacana kritis memiliki perbedaan yang mendasar. Dalam analisis wacana seseorang akan cenderung hanya mendeskripsikan struktur dari suatu wacana, sedangkan dalam analisis wacana kritis seseorang akan bertindak lebih jauh dari pada itu, misalnya dengan lebih menggali alasan mengapa suatu wacana memiliki struktur tertentu sehingga pada akhirnya akan berujung pada analisis hubungan sosial antara pihak yang berhubungan dengan wacana tersebut (Musyafa'ah, 2017). Selanjutnya, Darma (2009) mengungkapkan bahwa analisis wacana kritis merupakan suatu upaya mengurai wacana dan memberikan suatu penjelasan dari sebuah teks yang akan dikaji guna memperoleh apa yang diinginkannya.

Penelitian mengenai analisis wacana di media sering dilakukan misalnya pada kesalahan tata bahasa (Aprilia, Qoryah, and Aprilia 2020; Sari and Nurcahyo 2019). Namun belum banyak membahas dari struktur teks wacana itu sendiri. Wacana tentang Pilkada di tengah pandemi tentu menjadi bahasan menarik.

Pandemi covid-19 menjadi awal lahirnya problem-problem besar di Indonesia. Adanya pandemi ini telah merusak hampir seluruh tatanan kehidupan, tak terkecuali di bidang politik khususnya dalam hal pemilihan kepala daerah serentak yang kebetulan dilaksanakan pada tahun ini. Seharusnya pilkada ini dilaksanakan pada bulan September akan tetapi diundur menjadi bulan Desember. Dalam hal ini berbagai media massa online mulai menghadirkan wacana terkait hal tersebut. Salah satunya, yaitu wacana pemberitaan di kompas.com pada 24 September 2020 yang mengunggah wacana terkait pro dan kontra pelaksanaan pilkada serentak di tengah wabah pandemi covid-19. Tentunya pilkada serentak ini tidak begitu mendapat sambutan hangat dari masyarakat mengingat perintah berjaga jarak dan menghindari kerumunan, akan tetapi di sisi lain ada juga yang beranggapan dengan adanya pilkada ini mampu membantu pemerintah dan masyarakat untuk mengatasi permasalahan covid-19 di berbagai daerah melalui pemilihan pemimpin yang layak. Oleh karena itu, penulis mencoba menganalisis struktur wacana yang terdapat pada pemberitaan kompas.com tersebut menggunakan model analisis wacana kritis milik Teun Van Dijk. Model ini digunakan untuk menganalisis wacana (Saadillah and Nuruh 2020) Melalui model ini Van Dijk melihat suatu 
wacana terdiri dari tiga struktur tingkatan yang meliputi struktur makro, struktur superstruktur, dan struktur mikro. Berikut penjelasannya,

1. Struktur makro, struktur ini memiliki istilah lain tematik. Struktur ini menjadi makna global dari sebuah wacana. Dalam hal ini berisikan terkait tema atau gambaran umum perihal gagasan yang disampaikan oleh penulis dan menjadi konsep dominan atau sental dari wacana pemberitaan yang tengah dibahas.

2. Superstruktur, atau istilah lainnya skematik/alur. Sebuah wacana secara umum memiliki skema atau alur dari pendahuluan sampai penutup. Dengan alur tersebut mampu memperlihatkan seperti apa bagian-bagian atau struktur teks tersebut disusun dan diurutkan sehingga membuat sebuah kesatuan yang utuh. Dalam hal ini yang termasuk superstruktur, yaitu summary dan story (Anggraini, 2018). Pada bagian summary didalamnya terdapat lead, di mana lead ini berusaha untuk menjawab rumus $5 \mathrm{~W}+1 \mathrm{H}$ (Sobur, 2006).

3. Struktur makro, dalam struktur ini terdapat empat hal yang diamati, yaitu terkait semantik, sintaksis, stilistik, dan retoris (Sobur, 2006).

Dengan demikian, penggunaan teori model Teun Van Dijk diharapkan mampu menggambarkan konteks wacana pemberitaan pada kompas.com terkait pro kontra pelaksanaan pilkada serentak di tengah wabah covid-19 di Indonesia.

\section{METODE}

Penelitian ini menggunakan metode linguistik deskriptif. Metode ini dilakukan dengan cara mencatat dengan teliti terkait fenomena-fenomena kebahasaan yang ada di dalam pemberitaan online kompas.com edisi 24 September 2020. Sumber data penelitian ini diambil dari pemberitaan online kompas.com edisi 24 September 2020 dan data yang digunakan berupa kata, kalimat, dan ungkapan yang ada pada pemberitaan online kompas.com edisi 24 September 2020. Data dalam penelitian ini dikumpulkan dengan teknik dokumentasi dan studi literatur. Teknik dokumentasi digunakan untuk mencari data-data yang dibutuhkan melalui pemberitaan online kompas.com edisi 24 September 2020, sedangkan studi literatur sendiri digunakan untuk mencari referensi dan teori yang relevan dengan permasalahan yang akan dibahas dan dipecahkan. Kemudian, dari referensi-referensi yang ditemukan itulah yang akan menjadi fondasi atau alat utama bagi praktik penelitian. Selanjutnya, data yang telah terkumpul dianalisis menggunakan teori analisis wacana milik Teun Van Dijk (dalam Humaira, 2018) dan juga model analisis interaktif yang meliputi empat tahap, yaitu data collection, data reduction, data display, dan verifying (Sugiyono, 2018).

\section{HASIL DAN PEMBAHASAN}

Penelitian ini berupa penganalisisan wacana pro kontra pilkada serentak di masa pandemi covid-19 pada pemberitaan di media online kompas.com edisi 24 September 2020. Pemilihan wacana ini dikarenakan Indonesia saat ini tengah mengalami bencana yang 
membawa pengaruh pada tiap aspek kehidupan di masyarakat. Beberapa aktivitas diharuskan berjalan dari rumah, para pemudik juga dipersulit untuk pulang ke kampung halamannya, akan tetapi di sisi lain pilkada tetap berjalan meskipun ada pengunduran, yang mulanya harus dilaksanakan bulan September diundur menjadi bulan Desember. Maka dari itu, dalam wacana ini dibahas terkait pro dan kontra pelaksanaan pilkada serentak di masa pandemi covid-19 dan dari wacana tersebut penulis ingin mencoba membedah terkait struktur wacana tersebut menggunakan teori milik Teun Van Dijk. Analisis ini difokuskan kepada satu wacana dengan identitas sebagai berikut:

Judul : Alasan Pro dan Kontra Pilkada Serentak di Tengah Pandemi Covid-19

Waktu : Kamis, 24 September 2020, pukul 07:29 WIB

Penulis : Luthfia Ayu Azanella

Penerbit : Kompas.com

URL : https://www.kompas.com/trend/read/2020/09/24/072900565/alasan-pro-dankontra-pilkada-serentak-di-tengah-pandemi-covid-19?=3

\section{Struktur Makro}

Tematik atau makna global yang dibahas dalam wacana di kompas.com ini, yaitu terkait alasan pro dan kontra pilkada serentak di tengah pandemi covid-19. Melalui tema ini, penulis menggambarkan hal-hal apa saja yang melatarbelakangi adanya pro dan kontra dalam pilkada tahun ini.

\section{Superstruktur}

Superstruktur ini diklasifikasikan lagi menjadi dua bagian, yaitu

\section{a. Summary}

Tabel 1. Superstruktur (summary)

\begin{tabular}{|c|c|c|}
\hline NO & DATA TEMUAN & SUMMARY \\
\hline 1. & $\begin{array}{l}\text { Apa yang tengah diberitakan dalam wacana tersebut? } \\
\text { Beberapa pro dan kontra pilkada serentak di tengah pandemi covid-19 }\end{array}$ & Apa (what) \\
\hline 2. & $\begin{array}{l}\text { Siapa yang diberitakan dalam wacana tersebut? } \\
\text { Pengurus Besar Nahdlatul Ulama (PBNU) meminta supaya pelaksanaan } \\
\text { pilkada serentak } 2020 \text { ditunda. } \\
\text { Sekretaris Umum PP Muhammadiyah Abdul Mu'ti menjelaskan, usul } \\
\text { penundaan tersebut diungkapkan dengan alasan kemanusiaan di masa } \\
\text { pandemi covid-19. } \\
\text { Mantan Wakil Presiden RI Jusuf Kalla juga meminta pilkada ditunda } \\
\text { hingga tahun depan setelah vaksin ditemukan dan benar-benar efektif } \\
\text { mencegah penyebaran covid-19. } \\
\text { Hal itu diungkapkan Direktur Pusat Kajian Politik (Puskapol) Universitas } \\
\text { Indonesia (UI), Aditya Perdana } \\
\text {...karena sistem desentralisasi membagi kekuasaan pusat dan di daerah- } \\
\text { daerah pun juga terbagi lagi menjadi tingkat provinsi dan kabupaten/kota," } \\
\text { jelas Mendagri, Tito Karnavian. }\end{array}$ & Siapa (who) \\
\hline 3. & Mengapa muncul pro dan kontra dalam pilkada tahun ini? & Mengapa \\
\hline
\end{tabular}


Sebagian pihak menilai, pilkada serentak membuka potensi terjadinya penularan virus yang lebih massif di tengah masyarakat.

Namun di sisi lain, pilkada harus dilaksanakan demi mendapatkan pemimpin-pemimpin di daerah yang bisa menangani pandemi dengan maksimal.

4. Dimana pilkada serentak ini akan dilaksanakan?

Dimana

(where)

Dalam hal ini, makna tersirat ada pada wacana, yaitu pilkada serentak ini dilaksanakan di seluruh Indonesia.

5. Kapan rencananya pilkada serentak akan dilaksanakan?

Berbagai pro dan kontra mengiringi rencana pemerintah pusat untuk tetap menyelenggarakan pilkada serentak 9 Desember mendatang di tengah pandemi covid-19.

6. Bagaimana tanggapan beberapa orang terkait pemilu di tengah pandemi ini?

a) Selain meminta pilkada 2020 ditunda, PBNU juga meminta supaya anggaran pilkada direalokasikan bagi penanganan krisis kesehatan dan penguatan jaringan pengaman sosial.

b) Sementara dalam situasi pandemi, menurut Aditya, perlu kebijakan atau keputusan politik yang harus dilakukan dengan strategis dengan baik.

Hal yang disoroti dalam superstruktur bagian summary ini, yaitu lebih ke dalam pengenalan unsur $5 \mathrm{~W}+1 \mathrm{H}$ dalam membedah struktur wacana tersebut. Dalam struktur ini kita akan lebih memahami mengenai topik yang dibicarakan, siapa yang dibicarakan dan bagaimana permasalahannya. Seperti yang dipaparkan penulis dalam wacana tersebut, lima pendapat tokoh masyarakat akan pilkada serentak Desember mendatang. Beberapa tokoh ada yang mengatakan bahwa pilkada baiknya ditunda sampai tahun depan dan pemerintah diajak untuk fokus dalam menangani covid-19. Beberapa juga ada yang mengatakan bahwa pilkada penting dilakukan guna mengoptimalkan kinerja pemimpin dan menghindari adanya permasalahan baru. Tiga pendapat lebih menyatakan untuk kontra terhadap wacana pilkada Desember mendatang, yaitu Said Aqil Siroj, Abdul Mu'ti, dan Jusuf Kalla. Sedangkan dua pendapat pro terhadap pilkada Desember mendatang datang dari Aditya Perdana dan Tito Karnavian. Munculnya pro kontra pilkada pada tahun ini disebabkan karena adanya perbedaan beberapa tokoh dan masyarakat dalam menyikapi keberadaan pandemi.

\section{b. Story}

Story yang terdapat dalam wacana tersebut, yaitu terkait beberapa pendapat tokoh masyarakat terkait pelaksanaan pilkada 9 Desember 2020. Pendapat tersebut meliputi pro dan kontra, akan tetapi di akhir wacana lebih menekankan pada pro terhadap pilkada 9 Desember 2020 yang ditandai dengan dijelaskan bahwa pelaksanaan pilkada ini akan mematuhi protokol Kesehatan dengan pembuatan sanksi hukum bagi peserta yang tidak menaati protokol Kesehatan ketika tengah mengikuti acara pilkada. 


\section{Struktur Mikro}

\section{Tabel 2. Struktur Mikro}

\begin{tabular}{|c|c|c|}
\hline NO & $\begin{array}{l}\text { ELEMEN } \\
\text { WACANA }\end{array}$ & DATA TEMUAN \\
\hline 1. & $\begin{array}{l}\text { Semantik: } \\
\text { a. Latar }\end{array}$ & $\begin{array}{l}\text { Wacana yang dianalisis ini, berlatarkan penulis yang ingin } \\
\text { mengajak para pembaca paham akan pro dan kontra dari } \\
\text { beberapa tokoh ternama di Indonesia akan pelaksanaan pilkada } \\
\text { di tengah adanya wabah pandemi covid- } 19 \text {. }\end{array}$ \\
\hline & b. Detail & $\begin{array}{l}\text { a) Alasan Pro dan Kontra Pilkada Serentak di Tengah Pandemi } \\
\text { Covid-19 (judul) } \\
\text { b) Berbagai pro dan kontra mengiringi rencanna pemerintah pusat } \\
\text { untuk tetap menyelenggarakan Pilkada serentak } 9 \text { Desember } \\
\text { mendatang di tengah pandemi covid-19. } \\
\text { c) Ketua Umum PBNU Said Aqil Siroj mengatakan, dengan adanya } \\
\text { pandemi covid-19, prioritas utama kebijakan negara dan } \\
\text { pemerintah seharusnya diorientasikan pada pengentasan krisis } \\
\text { kesehatan. } \\
\text { d) "Kita bisa menyelenggarakannya pada Juni 2021. Memaksakan } \\
\text { sesuatu yang jelas-jelas secara rasional membahayakan kehidupan } \\
\text { rakyat bukan hanya nekat, melainkan fatal. Semua proses politik, } \\
\text { tujuan mulianya adalah untuk kemaslahatan rakyat. Bukan } \\
\text { memudaratkan rakyat," kata JK. } \\
\text { e) "Kalau PLT itu terbatas, tidak bisa melakukan putusan-putusan } \\
\text { yang strategis. Yang kedua waktunya juga terbatas, PLT itu tidak } \\
\text { bisa } 5 \text { tahun, seterusnya menjabat, waktunya dibatasi," kata Adit. } \\
\text { f) "Kalau setting-nya tepat, ini akan menjadi kontribusi dalam } \\
\text { rangka menekan (penyebaran) covid-19 ini. Di negara kita yang } \\
\text { menganut sistem demokrasi dengan desentralisasi, kendali sosial } \\
\text { kontrol akan sulit dikerjakan oleh pemerintah pusat sendirian, } \\
\text { karena sistem desentralisasi membagi kekuasaan pusat dan di } \\
\text { daerah-daerah pun juga terbagi lagi menjadi tingkat provinsi dan } \\
\text { kabupaten/kota," jelas Mendagri, Tito Karnavian. } \\
\text { g) Untuk memastikan semua protokol dijalankan dengan baik, maka } \\
\text { penerapan protokol kesehatan juga pelaksanaan aturan pemilu } \\
\text { akan diserti dengan sanksi hukum. }\end{array}$ \\
\hline
\end{tabular}

c. Maksud

Maksud wacana ini adalah untuk menginformasikan dan mengajak masyarakat khususnya pembaca untuk ikut memberikan opininya terkait kegiatan besar yang akan dilaksanakan pada bulan Desember 2020, yaitu terkait pilkada serentak di tengah wabah pandemi. Dalam wacana ini dihadirkan beberapa pendapat tokoh masyarakat diantaranya ada yang pro terhadap pelaksanaan pilkada juga beberapa ada yang kontra. Meskipun demikian, di akhir wacana ini diberi sebuah wacana positif akan pelaksanaan pilkada, yaitu dengan menghadirkan wacana akan diterapkannya protokol kesehataan saat dilaksanakannya pemilihan dan adanya sanksi hukum bagi yang tidak menaatinya.

2. Sintaksis
a. Bentuk kalimat

\section{Kalimat aktif:}

a) Berbagai pro dan kontra mengiringi rencanna pemerintah pusat untuk tetap menyelenggarakan Pilkada serentak 9 Desember 
mendatang di tengah pandemi covid-19.

b) "Kita bisa menyelenggarakannya pada Juni 2021. Memaksakan sesuatu yang jelas-jelas secara rasional membahayakan kehidupan rakyat bukan hanya nekat, melainkan fatal. Semua proses politik, tujuan mulianya adalah untuk kemaslahatan rakyat. Bukan memudaratkan rakyat," kata JK.

Kalimat pasif:

a) Dikutip dari Kompas.com (21/9/2020), Pengurus Besar Nahdlatul Ulama (PBNU) meminta supaya pelaksanaan pilkada serentak 2020 ditunda.

b) Usul penundaan tersebut diungkapkan dengan alasan kemanusiaan di masa pandemi covid-19.

b. Kata ganti

a) Menurut dia, keselamatan masyarakat di masa pandemi covid-19 merupakan yang paling utama. (kata ganti orang ketiga tunggal)

b) Di negara kita yang menganut sistem demokrasi dengan desentralisasi. (kata ganti orang pertama jamak)

c) Ada juga sanksi berdasarkan KUHP bagi mereka yang melanggar pasal-pasal tertentu dalam aturan yang digunakan. (kata ganti otang ketiga jamak)

c. Koherensi pengingkaran

Namun di sisi lain, pilkada harus dilaksanakan demi mendapatkan pemimpin-pemimpin di daerah yang bisa menangani pandemi dengan maksimal.

3. Stilistika

a) ...terjadinya penularan virus yang lebih massif di tengah masyarakat.

b) Semua proses politik, tujuan mulianya adalah untuk kemaslahatan rakyat. Bukan memudaratkan rakyat.

c) ...birokrasi pemerintah akan terhambat.

4. Retoris

a) Penulisan judul dibuat dengan huruf tebal dan lebih besar dibandingkan isi.

b) Di bawah judul terdapat gambar yang menunjukkan penerapan protokol Kesehatan, yaitu penataan meja yang berjarak, pengguaan APD, dan penyemprotan desinfektan.

c) Pro dan kontra dalam wacana ini disajikan dengan penggunaan poin-poin yang ditandai dengan sub-judul yang dipertebal.

d) Beberapa kosakata populer diberi warna biru dan jika diklik akan muncul berita seputar kosakata tersebut.

Pada struktur mikro, hal yang melatarbelakangi wacana ini adalah penulis yang ingin mengajak para pembaca paham akan pro dan kontra dari beberapa tokoh ternama di Indonesia akan pelaksanaan pilkada di tengah adanya wabah pandemi covid-19. Dalam hal ini penulis juga menjelaskan bahwasanya penundaan pilkada tidak memerlukan proses yang lama dan juga ditampilkan wacana positif, dimana dituliskan bahwa dalam pelaksanaan pilkada Desember mendatang akan diberlakukannya sanksi hukum bagi peserta yang tidak mengikuti protokol kesehatan. Dari segi sintaksis, ditemukan beberapa data yang menggunakan kalimat aktif dan juga pasif. Kalimat aktif sederhananya ditandai dengan penggunaan prefix me- dan ber-, sedangkan kalimat pasif ditandai dengan penggunaan prefix di-, ter-, dan ke-an. Kata 
ganti orang yang muncul dalam wacana ini berupa kata ganti orang ketiga tunggal (mendominasi), kata ganti orang pertama jamak, dan kata ganti orang ketiga jamak. Terkait stilistika, penulis penggunaan beberapa kosakata dan kalimat yang indah dan menarik seperti yang ditampilkan pada tabel di atas. Terakhir, terkait retoris hal yang paling menarik ketika membaca pemberitaan di media online adalah terkait penyajian beberapa kosakata populer yang dapat diklik dan memunculkan beberapa berita terkait kosakata tersebut, tentunya hal tersebut mampu mempermudah pembaca dalam mencari informasi mendetail menggunakan kosakata tersebut.

\section{KESIMPULAN}

Analisis wacana ini termasuk ke dalam jenis anawa kritis dengan menggunakan teori milik Teun Van Dijk untuk menganalisis sebuah wacana pemberitaan di media online berjudul Alasan Pro dan Kontra Pilkada Serentak di Tengah Pandemi Covid-19. Dalam teori ini wacana dibedah melalui struktur makro, superstruktur, dan struktur mikro dan semua struktur ini dapat ditemukan dalam wacana yang dianalisis. Jika dilihat dari segi story, penulis mencoba memaparkan terkiat pendabat beberapa tokoh masyarakat akan pelaksanaan pilkada serentak pada Desember 2020 di tengah wabah pandemic covid-19. Jika dilihat dari kemenarikan wacana tersebut, jika dilihat dari segi penyajiannya wacana online tersebut lebih unggul dibandingkan wacana non-online, salah satunya terkait beberapa kosakata populer diberi warna biru dan jika diklik akan muncul berita seputar kosakata tersebut.

\section{DAFTAR PUSTAKA}

Anggraini, Tri Riya. 2018. “Analisis Wacana Kritis Pada Koran Kompas Edisi 24 Mei 2012.” Jurnal Bindo Sastra 2(2):253-61.

Aprilia, Oky, Afifah Nuur Qoryah, and Oky Yahya Aprilia. 2020. “Analisis Kesalahan Berbahasa Bidang Morfologi Pada Portal Radar Solo Tema Covid-19.” Imajeri: Jurnal Pendidikan Bahasa Dan Sastra Indonesia 3(1):82-92.

Baryadi, Praptomo. 2002. Dasar-Dasar Analisis Wacana Dalam Ilmu Bahasa. Yogyakarta: Pustaka Gondhosuli.

Boer, Kheyene Molekandella, Mutia Rahmi Pratiwi, and Nalal Muna. 2020. "Analisis

Framing Pemberitaan Generasi Milenial Dan Pemerintah Terkait Covid-19 Di Media

Online." Communicatus: Jurnal Ilmu Komunikasi 4(1):85-104.

Darma, Y. 2009. Analisis Wacana Kritis. Bandung: Yrama Widya.

Fitriana, Riri Amanda, Erizal Gani, and Syahrul Ramadhan. 2019. "Analisis Wacana Kritis Berita Online Kasus Penipuan Travel Umrah (Model Teun A. Van Dijk).” Basindo: Jurnal Kajian Bahasa, Sastra Indonesia, Dan Pembelajarannya 3(1):44-54.

Humaira, Hera Wahdah. 2018. "Analisis Wacana Kritis (AWK) Model Teun A. Van Dijk

Pada Pemberitaan Surat Kabar Republika." Jurnal Literasi 2(1):32-40.

Musyafa'ah, Nurul. 2017. “Analisis Wacana Kritis Model Teun A. Van Dijk 'Siswa Berprestasi Jadi Pembunuh."” Modeling: Jurnal Program Studi PGMI 4(2):203-11. Nurkinan. 2017. "Dampak Media Online Terhadap Perkembangan Media Konvensional." Jurnal Politikom Indonesia 2(2):28-42.

Saadillah, Andi and H. Nuruh. 2020. “Analisis Wacana Kritis Teun Van Dijk Dalam Cerpen 'Tukang Dongeng' Karya Ken Hanggara.” Lingue: Bahasa, Budaya, Dan Sastra 2(2):80-87.

Sari, Kusuma and Rizki Joko Nurcahyo. 2019. “Analisis Kesalahan Berbahasa Pada Majalah Toga Edisi III Bulan Desember Tabun 2018." Imajeri: Jurnal Pendidikan Bahasa Dan Sastra Indonesia 2(1):11-23.

Sobur, Alex. 2006. Analisis Teks Media; Suatu Pengantar Untuk Analisis Wacana, Analisis 
Semiotik, Dan Analisis Farming. Bandung: PT. Remaja Rosdakarya.

Sugiyono. 2018. Metode penelitian kualitatif. 2nd ed. edited by S. Y. Suryandari. Bandung: Alfabeta.

Suprapto, Eko Agung Ady. 2020. "Wacana Moderasi Beragama Di Media Online (Analisis Wacana Moderasi Beragama Di Media Kompas. Com Dan Republika Online)." Suwandi, S. 2008. Serbalinguistik. Surakarta: Sebelas Maret University Press. 